\title{
Effect of Co and Mo Loading by Impregnation and Ion Exchange Methods on Morphological Properties of Zeolite Y Catalyst
}

\author{
Didi Dwi Anggoro ${ }^{1 *}$, Nur Hidayati², Luqman Buchori' ${ }^{1}$, Yayuk Mundriyastutik ${ }^{1}$ \\ ${ }^{1}$ Department of Chemical Engineering, Diponegoro University, Jl. Prof. Soedarto, Kampus Undip \\ Tembalang, Semarang 50239, Indonesia \\ ${ }_{2}^{2}$ Department of Chemical Engineering, Universitas Muhammadiyah Surakarta, Jl. A. Yani \\ Pabelan Kartasura, Tromol Pos I, Surakarta 57102, Indonesia
}

Received: 10th November 2015; Revised: $16^{\text {th }}$ January 2016; Accepted: $16^{\text {th }}$ January 2016

\begin{abstract}
Coal tar can be used as an alternative raw material for the production of liquid fuels, such as: gasoline and diesel through hydrogenation and cracking process. Hydrogenation and cracking process requires a catalyst which has metal components for hydrogenation reaction and acid components for cracking reaction. In this study, the $\mathrm{Co} / Z$ eolite $\mathrm{Y}$ and $\mathrm{Co}-\mathrm{Mo} / \mathrm{Z}$ eolite $\mathrm{Y}$ catalysts were prepared by impregnation and ion exchange methods. Characterizations of the catalysts were carried out by X-Ray Diffraction (XRD) and gravimetric acidity. The catalysts were tested for coal tar conversion to liquid fuel under various temperatures, amount of catalyst and hydrogen flow rates in a fixed bed flow reaction system. Liquid fuels products were analyzed by gas chromatography (GC). The XRD Spectra indicated that the addition of Co and Mo metals did not affect catalysts structure, however it alters the percentage of crystallinity. The addition of Co metal using impregnation method caused reduction in crystallinity, while the addition of Mo caused improvement of crystallinity. The Co-Mo/Zeolite Y catalyst with highest crystallinity was obtained by loading using ion exchange method. The addition of Co and Mo metals caused increasing acidity. However, the increasing composition of Co and Mo loaded on Zeolite Y catalyst decreased the yield of liquid fuels from coal tar. It can be concluded that the yields of liquid fuels and the composition of gasoline fractions from hydrocracking of coal tar were highly dependent on acidity of the catalyst. Copyright (C) 2016 BCREC GROUP. All rights reserved
\end{abstract}

Keywords: Coal tar; Cobalt; Molybdenum; Zeolite Y; Morphology

How to Cite: Anggoro, D.D., Hidayati, N., Buchori, L., Mundriyastutik, Y. (2016). Effect of Co and Mo Loading by Impregnation and Ion Exchange Methods on Morphological Properties of Zeolite Y Catalyst. Bulletin of Chemical Reaction Engineering \& Catalysis, 11 (1): 75-83.

(doi:10.9767/bcrec.11.1.418.75-83)

Permalink/DOI: http://dx.doi.org/10.9767/bcrec.11.1.418.75-83

\section{Introduction}

Due to its abundant reserve, coal has received major attention to replace petroleum as future primary energy source in Indonesia [1]. Coal is a solid fossil fuel containing a variety of

* Corresponding Author.

E-mail: anggorophd@gmail.com (D.D. Anggoro)

Telp./Fax.: +62247460058/ +622476480675 organic and inorganic components. Unfortunately, coal liquefaction has a negative effect to the environment due to the production of coal tar as by product. The liquefaction of 1 ton coal may produce 8-12 gallons of coal tar. Coal tar also contains aromatics, such as: benzene, toluene, phenol, and others that can be harmful to humans, fish, and wildlife [2]. Therefore, efforts to increase the economic value of coal tar by processing it into more useful materials 
such as fuel are urgently required.

Coal tar is produced from coal gasification process, commonly in the form of carbon darkviscous liquid of hydrocarbons $\mathrm{C}_{7-} \mathrm{C}_{20}$ with molecular weight of 200-1200 [3]. High molecular weight, viscosity and heteroatom compounds ( $\mathrm{S}$ and $\mathrm{N}$ ) have classified coal tar as a low quality fuel [4]. Coal tar contains a mixture of aliphatic, aromatic, alicyclic and heterocyclic components [2]. Coal tar can be used to produce liquid fuels, such as: gasoline and diesel oil, through the process of hydrocracking [5]. With the aim to enhance the hydrocracking ability of the catalysts, more acid supports, such as: zeolite and $\mathrm{TiO}_{2}$, have been used [6-11]. Besides, the conventional cracking function of the acidic sites, the catalytic activities for hydrogenation unsaturated compounds and removal of heteroatoms were also improved with zeolite supports [12-14].

Zeolite is considered as a low cost good catalyst, because it has large pores, surfaces area and high acidity. In the petroleum processing industry, zeolite was used as an acid catalyst in cracking [15]. The hydrocracking catalyst must have the ability to with hold from sulfur and nitrogen components contained in coal tar, so that the catalyst can be kept in good condition. Cobalt metal was selected for Zeolite Y catalyst modification due to its high selectivity and abil- ity to with hold the poison of sulfur and nitrogen components contained in coal tar. The incorporation of cobalt metal with zeolite $\mathrm{Y}$ and Co-Mo with zeolite $\mathrm{Y}$ can be done by method of impregnation or ion exchanges. Emelik et al. [16] and Tsitsihvli [17] have successfully conducted catalyst impregnation and ion exchange method for natural zeolite using $\mathrm{Ni}^{2+}$ solution. The results showed that $\mathrm{Ni}^{2+}$ ions were successfully incorporated into zeolite at concentration of $2.0 \mathrm{M}$ and temperature of $400^{\circ} \mathrm{C}$.

In this study, Co-Mo based zeolite $\mathrm{Y}$ catalysts were used as a hydrocracking catalyst for coal tar and resulted in light hydrocarbon fraction as liquid fuel. The purposes of the research are to analyze the effect of Co and Mo loaded zeolite $\mathrm{Y}$ based catalysts on catalyst morphology prepared by impregnation and ion exchange over coal tar hydrocracking.

\section{Materials and Methods}

\subsection{Materials}

Coal tar was obtained from PT. Sango ceramics Indonesia. The metal salts cobalt(II) nitrate hexahydrate, $\mathrm{Co}(\mathrm{No})_{3} .6 \mathrm{H}_{2} \mathrm{O}, 99 \%$ and ammonium molybda tetrahydrate, $\left(\mathrm{NH}_{4}\right)_{6} \mathrm{Mo}_{7} .4 \mathrm{H}_{2} \mathrm{O}, 99 \%$ from E. Merck Company. Zeolite Y obtained from Zeolyst International. Hydrogen gas from P.T. Samator, 99.99\%,

Table 1. Catalyst of Co-Mo/Zeolite Y prepared by ion exchange method

\begin{tabular}{|c|c|c|c|c|}
\hline \multirow{2}{*}{ Run } & \multicolumn{3}{|c|}{ Weight (gram) } & \multirow{2}{*}{ Catalyst Name } \\
\hline & Cobat & Molybdenum & Zeolite Y & \\
\hline 1 & 0 & 0 & 5 & $\mathrm{ZY}$ \\
\hline 2 & 2.0 & 0 & 5 & $2 \mathrm{Co} / \mathrm{ZY}$ \\
\hline 3 & 3.41 & 0.5 & 5 & $3.41 \mathrm{Co}-0.5 \mathrm{Mo} / \mathrm{ZY}$ \\
\hline 4 & 3.0 & 0.25 & 5 & $3 \mathrm{Co}-0.25 \mathrm{Mo} / \mathrm{ZY}$ \\
\hline 5 & 2.0 & 0.5 & 5 & $2 \mathrm{Co}-0.5 \mathrm{Mo} / \mathrm{ZY}$ \\
\hline 6 & 1.0 & 0.75 & 5 & $1 \mathrm{Co}-0.75 \mathrm{Mo} / \mathrm{ZY}$ \\
\hline 7 & 1.0 & 0.25 & 5 & $1 \mathrm{Co}-0.25 \mathrm{Mo} / \mathrm{ZY}$ \\
\hline 8 & 2.0 & 0.5 & 5 & $2 \mathrm{Co}-0.5 \mathrm{Mo} / \mathrm{ZY}$ \\
\hline 9 & 2.0 & 0.15 & 5 & $2 \mathrm{Co}-0.15 \mathrm{Mo} / \mathrm{ZY}$ \\
\hline 10 & 2.0 & 0.85 & 5 & $2 \mathrm{Co}-0.85 \mathrm{Mo} / \mathrm{ZY}$ \\
\hline 11 & 2.0 & 0.5 & 5 & $2 \mathrm{Co}-0.5 \mathrm{Mo} / \mathrm{ZY}$ \\
\hline 12 & 2.0 & 0.5 & 5 & $2 \mathrm{Co}-0.5 \mathrm{Mo} / \mathrm{ZY}$ \\
\hline 13 & 2.0 & 0.5 & 5 & $2 \mathrm{Co}-0.5 \mathrm{Mo} / \mathrm{ZY}$ \\
\hline 14 & 3.0 & 0.75 & 5 & $3 \mathrm{Co}-0.75 \mathrm{Mo} / \mathrm{ZY}$ \\
\hline 15 & 0.59 & 0.5 & 5 & $0.59 \mathrm{Co}-0.5 \mathrm{Mo} / \mathrm{ZY}$ \\
\hline
\end{tabular}


Pyridine 99.5\% from E. Merck Company.

\subsection{Catalyst preparation by impregnation}

Co-Mo/Zeolite Y catalyst was prepared by impregnation method [18] using the following steps: 0.59 gram $\mathrm{Co}\left(\mathrm{NO}_{3}\right)_{2} .6 \mathrm{H}_{2} \mathrm{O}$ and 0.5 gram $\left(\mathrm{NH}_{4}\right)_{6} \mathrm{Mo}_{7} \mathrm{O}_{24} .4 \mathrm{H}_{2} \mathrm{O}$ was dissolved in $25 \mathrm{ml}$ aquadest, and followed by addition of 5 grams of Zeolite Y. The mixture was stirred at $30{ }^{\circ} \mathrm{C}$ for 5 minutes and oven dried at $110^{\circ} \mathrm{C}$ for 24 hour. The dried mass was finally calcined in a box furnace at temperature $550{ }^{\circ} \mathrm{C}$ for 3 hour.

\subsection{Catalyst preparation by ion exchange}

The catalysts were prepared using an aqueous solution of bimetal Co and Mo compounds loaded on zeolite $\mathrm{Y}$ by ion exchange methods. The preparation are as follows: $\mathrm{Co}\left(\mathrm{No}_{3}\right)_{3} 6 \mathrm{H}_{2} \mathrm{O}$ and $\left(\mathrm{NH}_{4}\right)_{6} \mathrm{Mo}_{7} .4 \mathrm{H}_{2} \mathrm{O}$ dissolved in $25 \mathrm{~mL}$ aquadest with addition of 5 grams of zeolite $\mathrm{Y}$, as tabulated on Table 1. The mixture was stirred at $30{ }^{\circ} \mathrm{C}$ for $5 \mathrm{~h}$, followed by drying at $110{ }^{\circ} \mathrm{C}$ for $24 \mathrm{~h}$. Finally, the solid were calcined in a box furnace at temperature of $550{ }^{\circ} \mathrm{C}$ for 3 h.

\subsection{Characterization and testing catalyst}

Crystallinity of the catalyst samples were analyzed by X-Ray Diffraction (XRD) and total acid amount were analyzed by gravimetric using pyridine and ammonia gasses. The catalyst were tested for coal tar conversion to liquid fuel with hydrocracking processes carried out under variable operating conditions of temperature and pressure in a fixed bed tube reactor with 1 inch ID. The activity test were operated using three variables, i.e. amount of catalyst, temperature reaction and flow rate of $\mathrm{H}_{2}$. The liquid yields were analyzed by gas Chromatography (GC).

\section{Results and Discussion}

\subsection{Catalyst prepared by impregnation method}

3.1.1. Catalyst characterization by X-Ray Diffraction (XRD)

Based on XRD diffractogram (Figure 1) all samples have the same peaks, especially between $0-35^{\circ}$. The appeared $2 \theta$ of $35^{\circ}$ peak indicates the presence of Co and Mo metals in the surface of the catalyst. With similarities peak of both Zeolite $\mathrm{Y}$ and Co and Mo impregnated Zeolite $\mathrm{Y}$ catalysts, they indicate no change in crystal form in all samples of Zeolite Y catalyst. Base on some literatures, cobalt nitrate hexahydrate peaks should appear on $2 \theta$ of $15.10^{\circ}$; $15.61^{\circ} ; 27.06^{\circ} ; 28.09^{\circ} ; 30.55^{\circ}$ [19]. The percentage of crystallinity of catalysts is calculated by using Equation 1 using data from X-Ray Diffraction [20].

$\% X R D$ Crystallinity $=\frac{\text { sum of peak intensities of sample }}{\text { sum of peak intensities of reference }} \times 100 \%$

The effect of cobalt loading of Zeolite $\mathrm{Y}$ on catalyst crystallinity was tabulated in Table 2 . Table 2 showed that more cobalt added to Zeolite $\mathrm{Y}$ with the same amount of Mo, more the reduction in the percentage of crystallinity of catalyst. This is because the incorporated Co metal moved inside pores of the zeolite, and

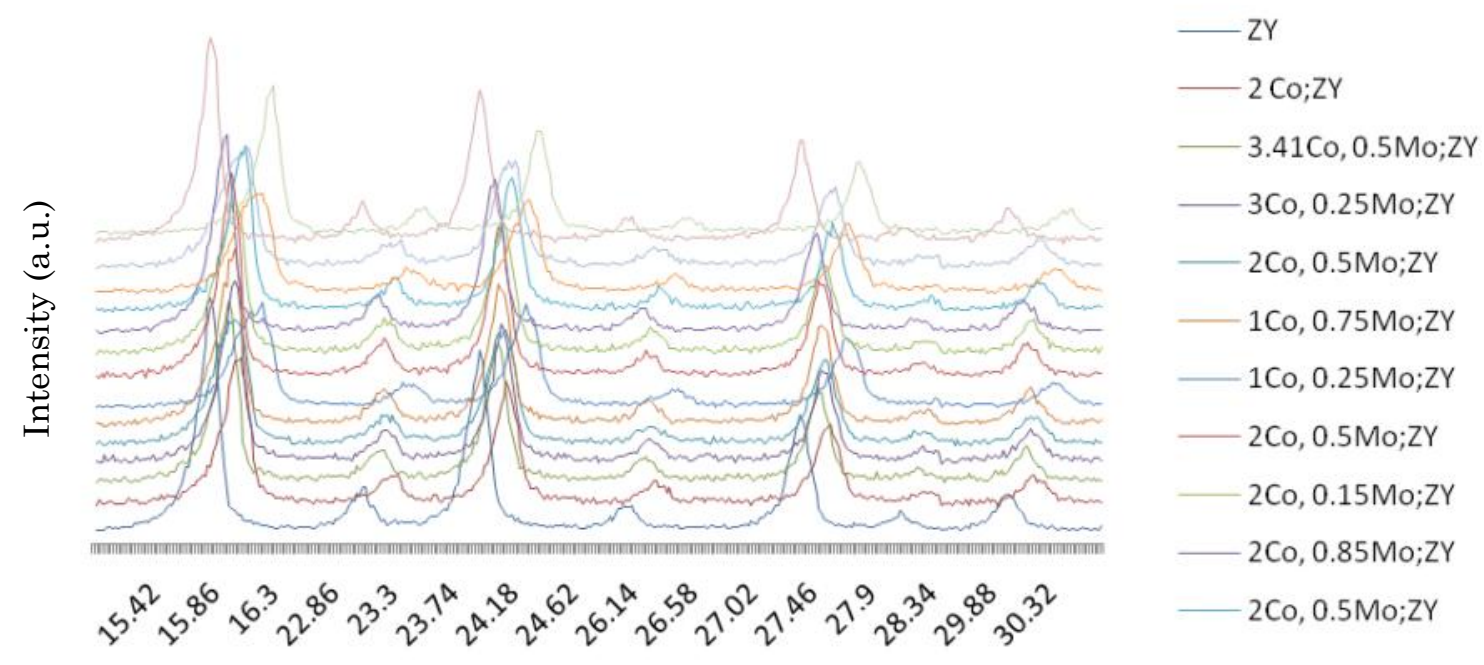

$2 \theta($ ( )

Figure 1. XRD Diffractogram of all catalyst samples obtained from impregnation method 
hence lowering catalyst crystallinity.

Table 3 shows the effect Mo loaded zeolite Y on catalyst crystallinity. It can be seen that more Mo is added to the catalyst with the same amount of $\mathrm{Co}$, the percentage of crystallinity of the catalyst improved significantly. This may be due to many of Mo metal attached on surface of the catalyst, thus forming crystals and increase the percentage of crystallinity.

\subsubsection{Characterization of the catalyst acidity} using ammonia gas gravimetry

Acidity analysis using gravimetric method employing ammonia gas was used to determine the acidity of a catalyst [21]. Effect of addition of Co on acidity of the catalyst samples is tabulated in Table 4. Table 4 shows that the addition of Co on Zeolite $\mathrm{Y}$ catalyst at the same amount of Mo increases the catalyst acidity. This may be due to the addition of Co caused the absorption of ammonia gas is increased.

Table 5 is tabulated the effect of Mo loaded

Table 2. Effect of Co on zeolite crystallinity

\begin{tabular}{ccc}
\hline Mo & Co & \% Crystallinity \\
\hline 0 & 0 & 93 \\
0 & 2 & 57 \\
0.5 & 0.59 & 83 \\
0.5 & 2 & 67 \\
0.5 & 3.4 & 63 \\
0.25 & 1 & 75 \\
0.25 & 3 & 60 \\
0.75 & 1 & 78 \\
0.75 & 3 & 68 \\
\hline
\end{tabular}

Table 4. Effect of Co on catalyst acidity

\begin{tabular}{ccc}
\hline Mo & Co & Acidity \\
\hline 0 & 0 & 11.06 \\
0 & 2 & 13.35 \\
0.5 & 0.6 & 9.19 \\
0.5 & 2 & 12.54 \\
0.5 & 3.4 & 15.20 \\
0.25 & 1 & 12.49 \\
0.25 & 3 & 13.66 \\
0.75 & 1 & 11.58 \\
0.75 & 3 & 15.53 \\
\hline
\end{tabular}

on the catalyst acidity. Table 5 showed that if the addition of Mo on the catalyst is increased with the same amount of $\mathrm{Co}$, it causes increased acidity of the catalyst. This is likely due to the Mo metal increases ammonia gas adsorption.

\subsubsection{Testing of catalyst}

The reactions mechanism of coal tar hydrocracking into liquid fuel are illustrated in Figure 2. Yield of liquid fuel depends on the catalyst acidity. Results of the catalysts testing under different amount of cobalt and molybdenum are tabulated in Table 6 . The reaction temperature was $350{ }^{\circ} \mathrm{C}$ and the catalyst amount of catalyst is 7 grams, i.e. 5 grams of catalyst which has been prepared (Co-Mo/Zeolite Y) and 2 grams of catalyst ZSM-5. Increasing of $\mathrm{X}_{1}$ (cobalt metal) to produce liquid fuel yield with range of $0.5-1.5 \%$ for $\mathrm{X}_{2}$ (molybdenum metal) to produce liquid fuel yield with range of $1-1.5 \%$. The increase in composition of cobalt metal and molybdenum metal leads to increased acid

Table 3. Effect of Mo on zeolite crystallinity

\begin{tabular}{ccc}
\hline Co & Mo & \% Crystallinity \\
\hline 2 & 0 & 57 \\
2 & 0.15 & 62 \\
2 & 0.5 & 67 \\
2 & 0.85 & 78 \\
3 & 0.25 & 60 \\
3 & 0.75 & 68 \\
1 & 0.25 & 75 \\
1 & 0.75 & 78 \\
\hline
\end{tabular}

Table 5. Effect of metal Mo on catalyst acidity

\begin{tabular}{ccc}
\hline Co & Mo & Acidity \\
\hline 2 & 0 & 13.35 \\
2 & 0.15 & 15.48 \\
2 & 0.5 & 12.54 \\
2 & 0.85 & 18.49 \\
3 & 0.25 & 13.66 \\
3 & 0.75 & 15.53 \\
1 & 0.25 & 12.49 \\
1 & 0.75 & 11.58 \\
\hline
\end{tabular}


value, and hence the yield on liquid fuels was decreased. This is because the effect on the hydrogenation of coal tar cracking on the acid value of the catalyst. The catalyst performance test indicated that the yield of liquid fuels decreased as the acid value increased.

\subsection{Catalyst prepared using ion ex- change method}

3.2.1. Catalyst characterization by X-Ray Diffraction (XRD)

Figure 3 indicates that $\mathrm{X}$-ray spectra of $\mathrm{Co}$ Mo/Zeolite Y catalyst has a similar pattern with Zeolite $\mathrm{Y}$ but in general show some differences in intensity at certain $2 \theta$. The differences indicate the amount of loaded metals

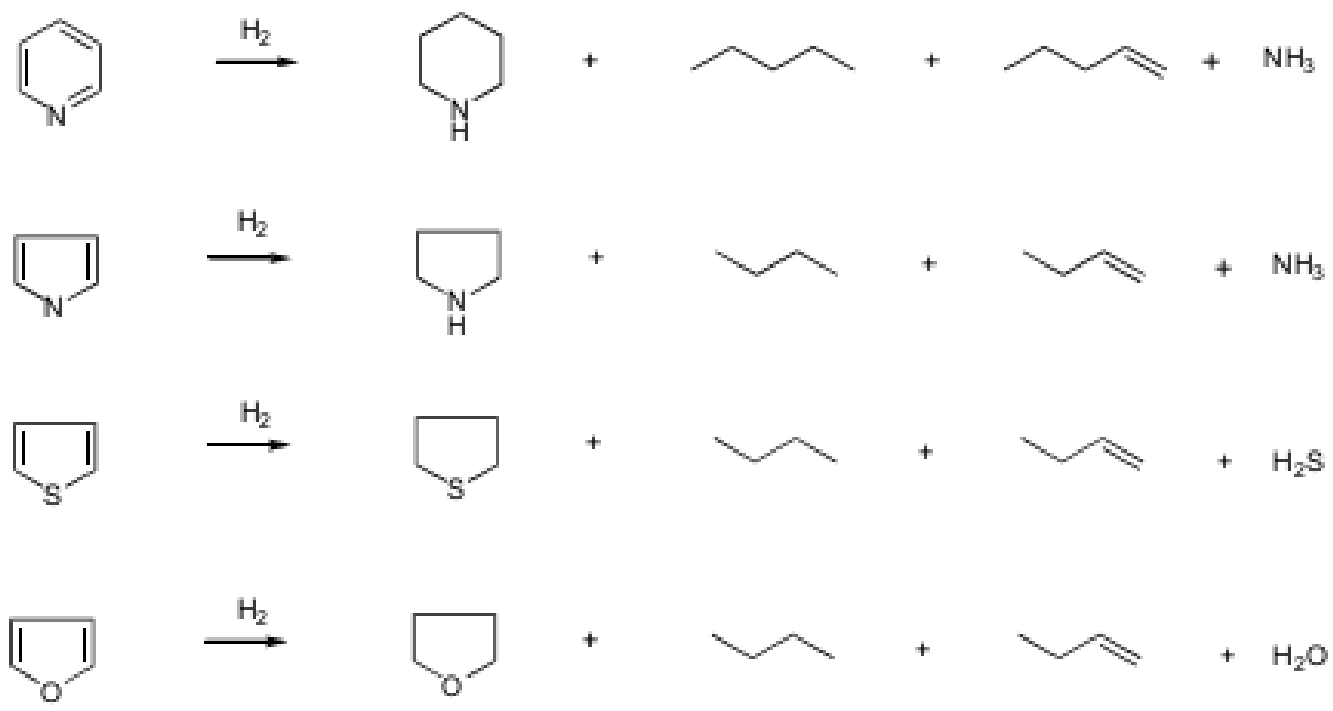

Figure 2. The mechanism reactions of hydrocracking coal tar into liquid fuel

Table 6. Testing hydrocracking coal tar when using catalyst by impregnation method

\begin{tabular}{|c|c|c|c|c|c|}
\hline \multirow{2}{*}{ Run } & \multicolumn{3}{|c|}{ Metals } & \multirow{2}{*}{ Liquid Fuel Yield (\%) } & \multirow{2}{*}{$\begin{array}{l}\text { Composition of gasoline } \\
(\%)\end{array}$} \\
\hline & Cobalt & Molybdenum & Zeolite Y & & \\
\hline 1 & 0 & 0 & 5 & $1.20 \%$ & 0.47 \\
\hline 2 & 2 & 0 & 5 & $0.50 \%$ & 1.13 \\
\hline 3 & 3.41 & 0.5 & 5 & $0.70 \%$ & 0.42 \\
\hline 4 & 3 & 0.25 & 5 & $0.45 \%$ & 2.13 \\
\hline 5 & 2 & 0.5 & 5 & $1.70 \%$ & 0.57 \\
\hline 6 & 1 & 0.75 & 5 & $1.40 \%$ & 0.99 \\
\hline 7 & 1 & 0.25 & 5 & $1.20 \%$ & 1.88 \\
\hline 8 & 2 & 0.5 & 5 & $1.35 \%$ & 3.57 \\
\hline 9 & 2 & 0.15 & 5 & $0.70 \%$ & 1.34 \\
\hline 10 & 2 & 0.85 & 5 & $1.00 \%$ & 4.24 \\
\hline 11 & 2 & 0.5 & 5 & $1.30 \%$ & 12.77 \\
\hline 12 & 2 & 0.5 & 5 & $1.50 \%$ & 1.90 \\
\hline 13 & 2 & 0.5 & 5 & $1.30 \%$ & 2.04 \\
\hline 14 & 3 & 0.75 & 5 & $1.50 \%$ & 2.05 \\
\hline 15 & 0.59 & 0.5 & 5 & $1.80 \%$ & 1.75 \\
\hline
\end{tabular}


[18]. The addition of Co and Mo metals to Zeolite $\mathrm{Y}$ causes the formation of amorphous structure on the Co-Mo/Zeolite Y.

The XRD spectra of the Zeolite Y and CoMo/Zeolite Y catalysts as depicted in Figure 3 show that Co and Mo loaded into Zeolite Y has crystallinity of $84.25 \%$. The loading of metal on Zeolite $\mathrm{Y}$ caused reduction in percentage of crystallinity on the catalyst. This is because the metals loading on the catalyst samples cover the surface of catalyst pores, which finally altered. Characteristics of the zeolite crystal as indicated by decreasing the intensity may be due to partial loss of structural cations of zeolite. However, the peak intensity of Zeolite Y decreases still within the limits of tolerance.

\subsubsection{Characterization of the catalyst acidity} using gravimetric method

The catalyst acidity test was carried out using gravimetric method with pyridine gas adsorption. Aim of this method is to determine the amount of acid sites on the catalyst. The results of Co-Mo/Zeolite Y concentration is $4.22 \mathrm{mmol} /$ gram pyridine. This result is higher than the amount of acidity of Zeolite Y, i.e. 3.09 $\mathrm{mmol} /$ gram pyridine. The increasing catalyst acidity caused the Mo metal loading into zeolites pore has 6 unpaired electrons in $d$ orbitals than loading Co metal having 3 unpaired electrons in $d$ orbital. The metals transition having full $d$ orbitals are not effective as electron - pair acceptors of adsorbate. As contributor of Lewis acid sites is able to increase the acidity of catalyst [22].

\subsubsection{Testing of catalyst}

Testing of catalyst for hydrocracking process of coal tar using Co and Mo loaded Zeolie $\mathrm{Y}$ catalysts were conducted by 16 experimental runs (Table 7), which used the response surface methodology by 3 factorials 4 star points, and 4 center points. The products of hydrocracking coal tar were hydrocarbons of $\mathrm{C}_{6}-\mathrm{C}_{11}$ or gasoline ranges. The chromatogram shows that the retention time of the compounds ranges from 1.8-18.50 similar to the standard gasoline $\mathrm{C}_{6}-\mathrm{C}_{11}$.

Table 7 indicated that the yield of liquid fuels using $\mathrm{Co}-\mathrm{Mo} / Z$ Zeolite $\mathrm{Y}$ catalyst is higher (1.9\%) than using Zeolite $\mathrm{Y}$ catalyst (1.0\%). This is due to that the acidity of Co-Mo/Zeolite $\mathrm{Y}$ catalyst is higher (3.88) than Zeolite Y catalyst (3.58). According to Wega et al. [21] stated the catalyst performance test and indicated that the yield of liquid fuels increased as the acid value increased.

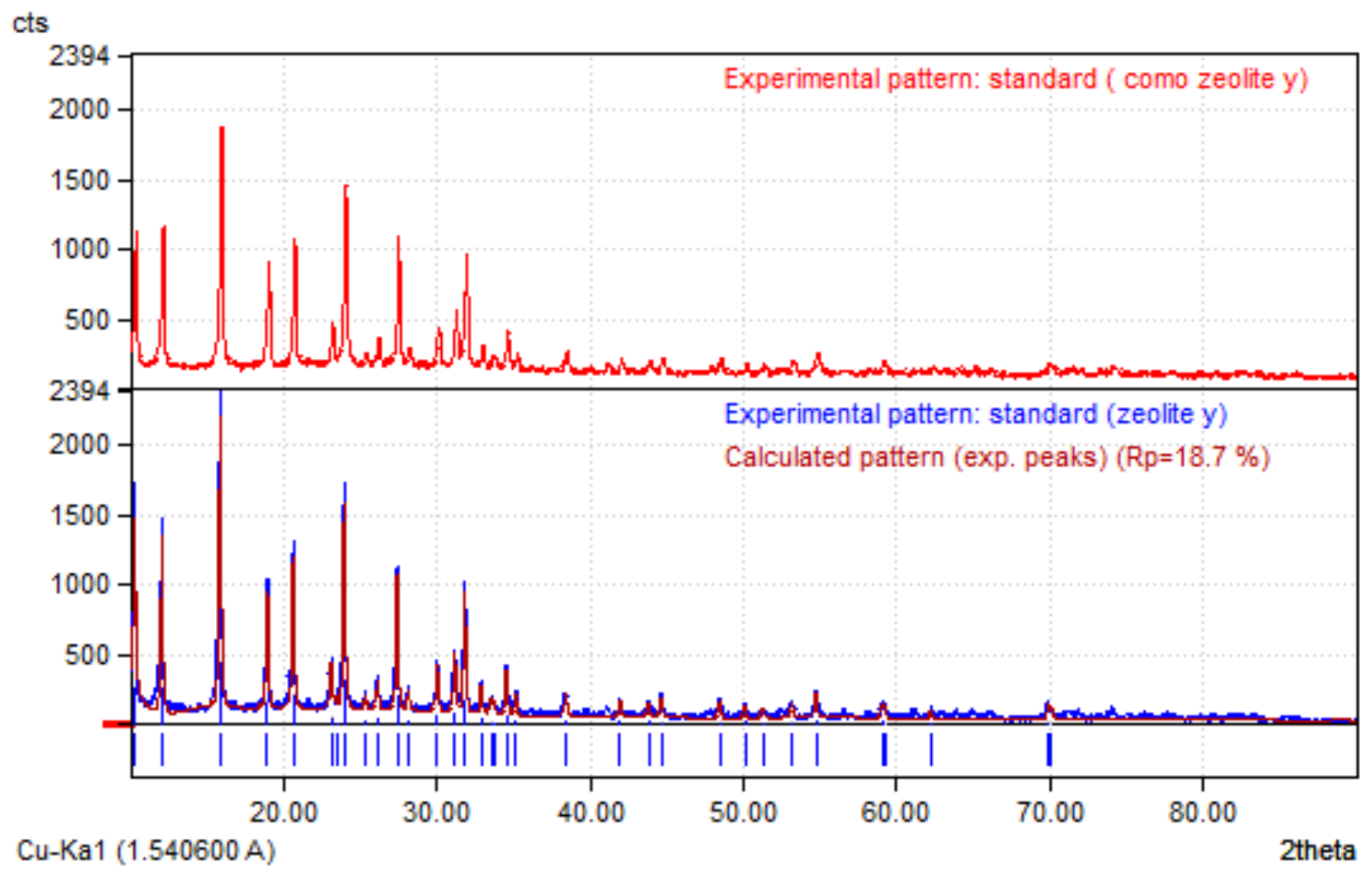

Figure 3. The XRD Spectra of the samples of zeolite $\mathrm{Y}$ and Co-Mo/zeolite $\mathrm{Y}$ 


\subsection{Comparison of effect of Co and Mo loaded Zeolite $\mathrm{Y}$ on catalyst morphology by impregnation and ion exchange meth- ods}

3.3.1. Catalyst characterization by X-Ray Diffraction (XRD)

The catalyst crystallinity of $0.59 \mathrm{~g}$ Co and 0.5 g Mo loaded Zeolite Y on catalyst morphology by impregnation and ion exchange methods from XRD analysis are $83 \%$ and $84 \%$, respectively. Higher catalyst crystallinity can be achieved by ion exchange method rather than impregnation method. This is because reduction of surface area of the metal loaded Co-Mo Zeolite $\mathrm{Y}$ indicates a strong interaction between the surface zeolite $\mathrm{Y}$ and Co and Mo [22] enabling good dispersion of the metals on the surface.

3.3.2. Characterization of the catalyst acidity using ammonia and pyridine gases gravimetric method

The acidity of catalyst using $0.59 \mathrm{~g}$ Co and $0.5 \mathrm{~g}$ Mo loaded Zeolite $\mathrm{Y}$ by impregnation method is higher than by ion exchange method. Comparing catalyst acidity using ammonia gas gravimetric of $0.59 \mathrm{Co}-0.5 \mathrm{Mo} /$ Zeolite $\mathrm{Y}$ catalyst using impregnation method obtained 9.19 $\mathrm{mmol} / \mathrm{gram}$, as well as by ion exchange was obtained of $4.22 \mathrm{mmol} / \mathrm{gram}$. The amount of acid sites indicated by ammonia adsorption is greater than the vapor of pyridine because it has stronger base than pyridine. The size of molecules contained ammonia relative smaller than pyridine so it is easier adsorp to the surface of the pore than pyridine only adsorb to the pore surface [23].

\subsubsection{Coal tar hydrocracking to liquid fuel}

The coal tar hydrocracking reaction was done using 5 grams of catalyst which was prepared (Co-Mo/Zeolite $\mathrm{Y}$ ) and 2 grams of catalyst ZSM-5 at $350{ }^{\circ} \mathrm{C}$ with a flow rate of 5 $\mathrm{mL} / \mathrm{min}$. The yield of liquid fuels using $0.59 \mathrm{~g}$ Co and $0.5 \mathrm{~g}$ Mo loaded zeolite $\mathrm{Y}$ catalyst using impregnation method was $1.8 \%$, while its gasoline composition was $1.75 \%$. The $0.59 \mathrm{Co}$ $0.5 \mathrm{Mo} /$ Zeolite $\mathrm{Y}$ catalyst of ion exchange method for hydrocracking of coal tar carried by using independent variable amount of catalyst, reaction temperature and hydrogen flow rate obtained optimum yield of $1.42 \%$ and gasoline composition $7.27 \%$.

A comparison of performance testing of catalyst obtained by impregnation method and ion exchange methods showed that the yields of liquid fuels using impregnation

Table 7. Testing hydrocracking coal tar using catalyst by ion exchange method

\begin{tabular}{|c|c|c|c|c|c|}
\hline \multirow[b]{2}{*}{ Run } & \multicolumn{3}{|c|}{ Independent variable } & \multicolumn{2}{|c|}{ Dependent variable } \\
\hline & $\begin{array}{l}\text { Amount of } \\
\text { catalyst }\left(\mathrm{X}_{1}\right) \\
(\mathrm{g})\end{array}$ & $\begin{array}{c}\text { Temperature } \\
\text { reaction }\left(\mathrm{X}_{2}\right) \\
\left({ }^{\circ} \mathrm{C}\right)\end{array}$ & $\begin{array}{c}\text { Flow rate } \mathrm{H}_{2} \\
\left(\mathrm{X}_{3}\right) \\
(\mathrm{mL} / \mathrm{min})\end{array}$ & $\begin{array}{l}\text { Composition } \\
\text { gasoline } \\
(\%)\end{array}$ & $\begin{array}{c}\text { Yield } \\
(\%)\end{array}$ \\
\hline 1 & 2 & 200 & 20 & 5.66 & 1 \\
\hline 2 & 2 & 200 & 60 & 15.5 & 1.1 \\
\hline 3 & 5 & 200 & 20 & 5.12 & 1 \\
\hline 4 & 5 & 200 & 60 & 12.23 & 1 \\
\hline 5 & 2 & 400 & 20 & 7.41 & 0.7 \\
\hline 6 & 2 & 400 & 60 & 17.82 & 1.1 \\
\hline 7 & 5 & 400 & 20 & 2.33 & 1.0 \\
\hline 8 & 5 & 400 & 60 & 1.02 & 0.5 \\
\hline 9 & 3 & 230 & 40 & 2.33 & 1.5 \\
\hline 10 & 3 & 53 & 40 & 25.81 & 0.6 \\
\hline 11 & 3 & 406 & 40 & 1.34 & 0.9 \\
\hline 12 & 0.35 & 230 & 40 & 3.79 & 0.6 \\
\hline 13 & 5.65 & 230 & 40 & 1.89 & 1.0 \\
\hline 14 & 3 & 230 & 4 & 3.32 & 1.0 \\
\hline 15 & 3 & 230 & 75 & 7.41 & 1.9 \\
\hline 16 & 3 & 230 & 40 & 3.39 & 1.5 \\
\hline
\end{tabular}


method is higher than the ion exchange method. However, catalyst obtained by ion exchange method results in higher composition of gasoline fractions. This indicates that a process of reaction formation via carbocation, where each ion carbonium production will induce other compounds to form new carbonium ion with a smaller number of atoms, with the addition of metallic Co and Mo can improve high activity in the hydrocracking of coal tar. It is evident from the high results of the composition of the product. In addition to the greater composition of metals, cobalt and molybdenum metals also affect the process of hydrogenation of coal tar cracking in the power value of the acid catalyst. Lin et al. [24] showed that the activation energy of a reaction will decrease drastically with increasing acid strength of a catalyst, especially in the process that has a lot of reaction.

\section{Conclusions}

Loading of Co and Mo on Zeolite Y catalyst prepared by using impregnation and ion exchange method did not change the structure of catalysts. The percentage of catalyst crystallinity for catalyst prepared by ion exchange method was high, while acidity of the catalyst was high for the catalyst prepared by using impregnation. The yields of liquid fuels using impregnation method was greater than using ion exchange method, however composition of fractions gasoline greater if using ion exchange method. These results can be concluded that the yields of liquid fuels and the composition of fraction gasoline from hydrocracking of coal tar depend on the acidity of catalyst. If the acidity of catalyst was high, the yield of liquid fuels was increased, however the composition of gasoline fraction was decreased.

\section{Acknowledgments}

The authors gratefully acknowledge the financial support from Diponegoro University DIPA Number 214-05/UN7.5.1/PG / 2015 and support from PT. Sango Ceramic Indonesia for Feedstock Coal Tar.

\section{References}

[1] Anonim. (2013, Januari). Energi Sumber Daya Mineral (ESDM). Retrieved on Oktober 15, 2013, from http://www.esdm.go.id/ statistik/data-sektor-esdm/cat_view/58 publikasi/240-statistik/341-statistik-minyakbumi.html.

[2] Kan, T., Wang, H., He, H., Li, C., Zhang, S., (2011) Experimental Study on Two-stage catalytic hydroprocessing of middle- temperature Coal tar to clean liquid fuels, Fuel, 90: 3404-3409.

[3] Rokhati, N. (1999). Pirolisis Tir Batu Bara Secara Sinambung, Master Thesis. Universitas Gajah Mada (in Indonesian)

[4] Krichko, A.A., Maloletnev, A.S., Mazneva, O., Gagarin, S.G (1996). Catalytic Properties of High-Silica Zeolite in Hydrotreatment of Coal Liquefaction Product, Fuel, 76: 683685.

[5] Fanani, Z. (2010). Hidrocrakcing Tir Batubara Menggunakan Katalis Ni-Mo-S/ZAA untuk Menghasilkan Fraksi Bensin dan Fraksi Kerosen, Jurnal Penelitian Sains, 1006, (08) 22-33

[6] Sayan, S, Paul, J. (2002) Hydrogenation of naphthalene and methylnaphthalene: Modeling and spectroscopy. J. Molec. Catal. A: Chem., 185: 211-222.

[7] Ramirez, J., Rayo, P., GutiRrez-Alejandre, A., Ancheyta, J., Rana, M.S. (2005) Analysis of the hydrotreatment of Maya heavy crude with NiMo catalysts supported on $\mathrm{TiO}_{2}$ $\mathrm{Al}_{2} \mathrm{O}_{3}$ binary oxides: Effect of the incorporation method of Ti. Catal. Today, 109: 54-60.

[8] Wang, L., Shen, B., Fang, F., Wang, F., Tian, R., Zhang, Z., Cui, L. (2010) Upgrading of light cycle oil via coupled hydrogenation and ring-opening over $\mathrm{NiW} / \mathrm{Al}_{2} \mathrm{O}_{3}$-USY catalysts. Catal. Today 158: 343-347.

[9] Arribas, M.A., Martınez, A. (2002) The influence of zeolite acidity for the coupled hydrogenation and ring opening of 1 methylnaphthalene on Pt/USY catalysts. Appl. Catal. A: Gen., 230: 203-217.

[10] Leite, L., Benazzi, E., Marchal-George, N. (2001) Hydrocracking of phenanthrene over bifunctional Pt catalysts. Catal. Today, 65: 241-247.

[11] Hassan, A., Ahmed, S., Ali, M.A., Hamid, H., Inui, T. (2001) A comparison between [beta]and USY-zeolite-based hydrocracking catalysts. Appl. Catal. A: Gen., 220: 59-68.

[12] Gallezot, P. (1979) The state and catalytic properties of platinum and palladium in faujasite-type zeolites. Catal. Rev. Sci. Eng. 20: 121-154.

[13] Zheng, J., Guo, M., Song, C. (2008) Characterization of Pd catalysts supported on USY zeolites with different $\mathrm{SiO}_{2} / \mathrm{Al}_{2} \mathrm{O}_{3}$ ratios for the hydrogenation of naphthalene in the presence of benzothiophene. Fuel Process. Technol., 89: 467-474.

[14] Yasuda, H., Sato, T., Yoshimura, Y. (1999) Influence of the acidity of USY zeolite on the sulfur tolerance of $\mathrm{Pd}-\mathrm{Pt}$ catalysts for aromatic hydrogenation. Catal. Today, 50: 6371. 
[15] Chorkendorff, Niemantsverdriet, (2003) Concepts of Modern Catalyst and Kinetics, WILEY-VSH Verlag GmbH \& Co. KGaA, Weinheim.

[16] Emelik, B., (1980) Catalysis by Zeolite, Proceeding of an International Symposium, Elsevier Scientific, Publishing Co, New York.

[17] Tsitsishvili, G.V. (1992) Natural Zeolites, Ellis Horwood. New York,16-19.

[18] Zeno, R.R., Tria, F. (2015), Effect of Co and Mo Metal Addition in Co-Mo/Zeolite Y Catalyst for Coal Tar Conversion To Liquid Fuel, Undergraduate Thesis, Chemical Engineering, Diponegoro University.

[19] Li, L., Quan, K., Xu, J., Liu, F., Liu, S., Yu, S., Xie, C., Zhang, B., Ge, X. (2014) Liquid hydrocarbon fuels from catalytic cracking of rubber seed oil using USY as catalyst, Fuel, 123: 189193.

[20] Nicolaides, C.P. (1999). A novel family of solid acid catalysts: substantially amorphous orpartially crystalline zeolitic materials, Applied Catalysis A: General 185: 211-217.
[21] Trisunaryanti, W. (2002) Optimation of Time and Catalyst/Feed Ratio in Catalytic Cracking of Waste Plastics Fraction to Gasoline Fraction Using Cr/Natural Zeolite Catalyst, Indonesian Journal of Chemistry, 2: 3040.

[22] Anggoro, D.D, Amin, N.A.S. (2006) Methane to Liquid Hydrocarbons over Tungsten-ZSM5 and Tungsten Loaded Cu/ZSM-5 Catalysts, Journal of Natural Gas Chemistry 15: 340-347.

[23] Trisunaryanti, W., Purwono, S., Putra, A. (2008) Catalytic Hydrocracking of Waste Lubricant Oil Into Liquid Fuel Fraction Using $\mathrm{ZnO}, \mathrm{Nb}_{2} \mathrm{O}_{5}$, Activated Natural Zeolite Their Modification, Indo. J. Chem., 342-347.

[24] Lin, L., Qiu, C., Zhuo, Z., Zhang, D., Zhao, S., Wu, H., Liu, Y., He, M. (2014) Acid Strength Controlled Reaction Pathways for the Catalytic Cracking of 1-Butene to Propene over ZSM-5, Journal of Catalysis, 309: 136-145.

Selected and Revised Papers from The $2^{\text {nd }}$ International Conference on Chemical and Material Engineering 2015 (ICCME 2015) (29-20 September, 2015, Semarang, Indonesia)

(http://econference.undip.ac.id/index.php/iccme/2015) after reviewed by Peer-Reviewers of ICCME 2015 and BCREC Journal 